\title{
Role of p53 as a prognostic factor for survival in lung cancer: a systematic review of the literature with a meta-analysis
}

\author{
E. Steels*, M. Paesmans*, T. Berghmans*, F. Branle*, F. Lemaitre*, C. Mascaux*, A.P. Meert*, \\ F. Vallot*, J.J. Lafitte ${ }^{\#}$, J.P. Sculier*
}

Role of p53 as a prognostic factor for survival in lung cancer: a systematic review of the literature with a meta-analysis. E. Steels, M. Paesmans, T. Berghmans, F. Branle, F. Lemaitre, C. Mascaux, A.P.Meert, F. Vallot, J.J. Lafitte, J.P. Sculier. (C)ERS Journals Ltd 2001.

ABSTRACT: The role of $\mathrm{p53}$, as a prognostic factor for survival in lung cancer, is controversial and the purpose of the present systematic review of the literature is to determine this effect.

Published studies were identified with the objective to aggregate the available survival results after a methodological assessment using a scale specifically designed by the European Lung Cancer Working Party (ELCWP). To be eligible, a study had to deal with p53 assessment in lung cancer (primary site) only, and to provide a survival comparison according to the p53 status.

Among the 74 eligible papers, 30 identified p53 abnormalities as a univariate statistically significant poor prognostic factor and 56 provided sufficient data to allow survival results aggregation. There was no significant difference between the trials that either showed or did not show a prognostic effect of p53 according to the methodological score or to the laboratory technique used. The studies were categorized by histology, disease stage, treatment and laboratory technique. Combined hazard ratios suggested that an abnormal p53 status had an unfavourable impact on survival: in any stage nonsmall cell lung cancer (NSCLC) the mean $(95 \%$ confidence interval) was $1.44(1.20-1.72)$ (number of studies included in the subgroup was 11), $1.50(1.32-1.70)$ in stages I-II NSCLC $(n=19), 1.68(1.23-2.29)$ in stages I-IIIB NSCLC $(n=5), 1.68$ $(1.30-2.18)$ in stages III-IV NSCLC $(n=9), 1.48(1.29-1.70)$ in surgically resected $\operatorname{NSCLC~}(n=20), 1.37(1.02-1.85)$ in squamous cell carcinoma $(n=9), 2.24(1.70-2.95)$ in adenocarcinoma $(n=9), 1.57(1.28-1.91)$ for a positive immunohistochemistry with antibody $1801(n=8), 1.25(1.09-1.43)$ for a positive immunohistochemistry with antibody DO-7 $(\mathrm{n}=16)$, and $1.65(1.35-2.00)$ for an abnormal molecular biology test $(n=13)$. Data were insufficient to determine the prognostic value of p53 in small cell lung cancer.

In each subgroup of nonsmall cell lung cancer, p53 abnormal status was shown to be associated with a poorer survival prognosis.

Eur Respir J 2001; 18: 705-719.

\begin{abstract}
*Dépt de Médecine et Laboratoire d'Investigation Clinique H.J. Tagnon, Institut Jules Bordet, Centre des Tumeurs de l'Université Libre de Bruxelles, Brussels, Belgium and "Service de Pneumologie et Oncologie Thoracique, Centre Hospitalo-Universitaire Calmette, Lille, France.
\end{abstract}

Correspondence: J.P. Sculier

Service de Médecine

Institut Jules Bordet

1 rue Héger Bordet

B-1000 Brussels

Belgium

Fax: 3225343756

Keywords: Lung cancer

meta-analysis

p53

prognosis

survival

systemic review

Received: July 72000

Accepted after revision April 122001
Lung cancer is the most common cause of cancer death in industrialized countries and its incidence is steadily increasing in females and in many European countries. Despite improvements in diagnosis and therapy, the overall 5-yr survival is still $15 \%$.

Some independent prognostic factors have been identified for predicting survival and helping in the management of patients with lung cancer [1]. They include: for small cell lung cancer (SCLC), extent of disease and performance status (PS) [2]; for resectable nonsmall cell lung cancer (NSCLC), PS, tumour, node, metastasis (TNM) stage, and age [3]; for advanced NSCLC, PS, TNM stage, age, sex and weight loss [4, 5]. Among biological factors, white blood cell count, serum lactate dehydrogenase level, angiogenesis and factors reflecting proliferative state have been shown to significantly predict outcome $[6,7]$.

Recent progresses in molecular biology have allowed for the extension of the research on prognostic factors to the analysis of proteins and genes involved in cancer development. For example, factors related to growth (e.g. epithelial growth factor, erb$\mathrm{B} 2)$, cell cycle (e.g. retinoblastoma gene), or apoptosis (e.g. p53 and bcl-2) have been studied in recent publications, in order to correlate them with survival [8-11].

p53 has been the topic of numerous publications in lung cancer patients. It is a $53-\mathrm{kD}$ nuclear phosphoprotein, produced by the p53 tumour suppressor gene, 
which is localized on human chromosome $17 \mathrm{p} 13$. It binds to double-stranded deoxyribonucleic acid (DNA) and has three main physiological functions: cell cycle regulation, induction of apoptosis, and stabilization of the genome [12]. Mutations of the p53 gene are implicated in the carcinogenesis of many cancers and are commonly found in lung cancer $[13,14]$.

Despite the large number of studies, the prognostic value of $\mathrm{p} 53$ for survival in patients with lung cancer is controversial, numerous studies published in this field deal with a small series of patients. Therefore, a systematic review of the literature has been performed to assess the prognostic value of p53 abnormalities for the survival of patients presenting with lung cancer.

\section{Materials and methods}

\section{Publications selection}

Criteria for eligibility of a study to the present systematic review were: to deal with lung cancer only; to evaluate the correlation between p53 status and patient survival; to analyse p53 (protein, DNA or ribonucleic acid (RNA) in the primary tumour (not in metastatic tissue, or in tumour adjacent tissue) and/ or antibodies against p53 in the serum; to be published as a full paper in the English or French language literature.

Articles were identified by an electronic search on MEDLINE using the keywords "lung neoplasm" and "p53", completed by the personal bibliography of two of the authors. The bibliographies reported in any of the studies identified were also used for the trials of identification. The search ended in July 1999.

When the same author reported results obtained on the same patient population, in several publications, only the most recent or the most complete report was included in the analysis (to avoid overlap between cohorts).

The review was limited to the published studies and no contact was made with the authors to obtain unpublished data.

\section{Methodological assessment}

To assess the trial methodology (the Wording trial, to refer to a clinical research study, is used in the present paper), 10 investigators, including nine physicians and one biostatistician, read each publication independently and scored them according to a quality scale as described in the Appendix. Each item was assessed using an ordinal scale (possible values: $2,1,0$ ).

The scores were compared and a consensus value for each item was reached in meetings at which at least two-thirds of the investigators needed to be present. The participation of many readers was a guarantee for the correct interpretation of the articles. As the scores were objective, a consensus was always obtainable.

The overall score evaluated several dimensions of the methodology, grouped into four main categories: the scientific design; the description of the methods used to identify an abnormality of the p53 status (abnormality meaning presence of a mutated gene, a detectable protein or anti-p53 antibodies); the generalizability of the results; the analysis of the study data.

Each category had a maximum score of 10 points, hence the overall maximum score was 40 points. When an item was not applicable in a study, the theoretically attributable points were not taken into account in the total of the concerned category. The final scores were expressed as percentages, ranging $0-100 \%$, higher values indicated a better methodological quality.

The studies eligible for the systematic review were called "eligible" and those providing data for the meta-analysis "evaluable". Only studies reporting univariate analysis results for survival were considered for the aggregation of the survival data.

\section{Statistical methods}

The results of a study were considered significant if the p-value for the statistical test comparing the survival distribution between the groups with and without abnormalities in the status of $\mathrm{p} 53$, was $<0.05$ in favour of the group without abnormalities. The study was then called "positive" (which meant that abnormalities were a poor prognosis for survival). If authors reported a significant result in a subgroup analysis only, the study was also considered to be positive. In the other situations it was called "negative", including the situation where a significant survival difference was found in favour of the group of patients with p53 abnormalities.

The correlation between the quality scores, or two continuous variables, was measured by the Spearman rank correlation coefficient. Its significance was assessed by testing the null hypothesis of equality to zero of this coefficient. Nonparametric tests were used to compare the distribution of the quality scores according to the value of a discrete variable (MannWhitney U-tests for binary variables and KruskalWallis tests for multiple class variables).

For the quantitative aggregation of the survival results, the p53 effect was measured by the hazard ratio (HR) between the two survival distributions. For each trial, this HR was estimated by a method depending on the results provided in a previous publication [15]. The most accurate method comprised of retrieving the HR estimate and its variance from the reported results, or calculating them directly using parameters given by the authors for the univariate analysis: the O-E statistic (difference between numbers of observed and expected events), the confidence interval (CI) for the HR, the logrank statistic or its p-value. If these were not available, the total number of events, the number of patients at risk in each group and the logrank statistic or its p-value were used to allow for an approximate calculation of the HR estimate. Finally, if the only exploitable data were in the form of graphical representations of the survival distributions, survival rates at some specified times were extracted from them in order to reconstruct the HR estimate and its variance, with the assumption 
that the rate of patients censored was constant during the study follow-up. If authors reported survival of three or more groups (for example, using several cutoff values for percentage of protein present in the nucleus, or regarding the exons of DNA separately) the results were pooled, making a comparison between two groups feasible.

Survival of the entire patient population, when available, was analysed globally, according to the p53 status. If results in particular subgroups were reported separately, they were treated in the meta-analysis of the corresponding subgroups. Of course, the same patients were never considered more than once in the same analysis. The individual HR estimates were combined into an overall HR using the method published by YusuF et al. [16], which consists of using a fixed-effects model with the assumption of the homogeneity of the individual HRs. This assumption was tested by performing Chi-squared tests for heterogeneity, as previously described [16]. The possible heterogeneity among the HRs was first taken into account by categorizing the studies according to some of the covariates (histology, stage, treatment, or laboratory method) known to be prognostic factors in lung cancer, rather than considering a random-effects model. However, if the assumption of homogeneity had to be rejected for some defined subgroups, a random-effects model was used in a second stage for these particular subgroups. By convention, an observed HR $>1$ implied a worse survival for the group with p53 abnormalities. This pejorative impact of p53 on survival was considered as statistically significant if the $95 \% \mathrm{CI}$ for the overall HR did not overlap 1.

\section{Results}

\section{Study selection and characteristics}

Seventy-nine trials, published between 1992-1999, were selected [9-11, 17-92]. They all reported the prognostic value for survival of p53 status in lung cancer patients, assessing p53 gene abnormality or protein expression in the primary tumour, or antibody anti-p53 presence in the serum. Five of these studies were excluded because an identical patient cohort had been used in other selected publications (studies that were excluded and included were [39, 40, 43, 44, 71, 72, 84-87].

The main characteristics of the 74 studies eligible for the systematic review are shown in table 1. Sixtyseven of them dealt with NSCLC, while SCLC, neuroendocrine tumours, and any histological type were the subject of 2, 2 and 3 trials, respectively. The NSCLC studies considered either all subtypes $(n=57)$, adenocarcinoma $(n=6)$, or squamous cell carcinoma $(n=4)$. Fifty of the 67 NSCLC studies assessed locoregional disease, treated by surgery alone in $76 \%$ of cases.

Some studies evaluated the prognostic role of $\mathrm{p} 53$ gene mutations, identified by molecular biology $(\mathrm{n}=18)$, with polymerase chain reaction (PCR), most frequently followed by single-strand conformation polymorphism (SSCP) method, or by denaturing gradient gel electrophoresis (DGGE), or by DNA sequencing. One study assessed the RNA abnormalities by a reverse-transcription PCR-SSCP method. The others evaluated the accumulation of p53 protein either by immunohistochemistry (IHC) detection $(n=49)$, by optic microscopy or flow cytometry, or by an enzyme-linked immunosorbent assay technique (ELISA) on cellular extracts $(n=2)$. Five studies investigated the role of p53 antibodies in sera by ELISA, Western blot or immunoblot test.

Three trials evaluated both p53 DNA and protein; they were considered in the present analysis for DNA results only, the protein accumulation not being strictly correlated with gene mutation. One study assessed both p53 protein accumulation in the primary tumour and presence of antibodies in the sera, and was considered for the protein analysis only.

Amongst the 74 trials eligible for systematic review, it was not possible to evaluate 18 for the HR estimation due to insufficient reported data, and

Table 1. - Main characteristics and results of the eligible studies

\begin{tabular}{|c|c|c|c|c|c|c|c|c|c|c|c|c|}
\hline & \multicolumn{2}{|c|}{ All studies } & \multicolumn{2}{|c|}{$\begin{array}{l}\text { NSCLC } \\
\text { any stage }\end{array}$} & \multicolumn{2}{|c|}{$\begin{array}{c}\text { NSCLC } \\
\text { locoregional (I-IIIB) }\end{array}$} & \multicolumn{2}{|c|}{$\begin{array}{l}\text { SCLC } \\
\text { any stage }\end{array}$} & \multicolumn{2}{|c|}{$\begin{array}{l}\text { Neuroendocrine } \\
\text { tumours }\end{array}$} & \multicolumn{2}{|c|}{$\begin{array}{l}\text { Any histology } \\
\text { any stage }\end{array}$} \\
\hline & Total & $\mathrm{S}$ & Total & $\mathrm{S}$ & Total & $\mathrm{S}$ & Total & $\mathrm{S}$ & Total & $\mathrm{S}$ & Total & $\mathrm{S}$ \\
\hline Number of studies & $74(56)$ & $30(28)$ & $17(13)$ & $5(4)$ & $50(37)$ & $23(22)$ & $2(2)$ & 0 & $2(1)$ & $1(1)$ & $3(3)$ & $1(1)$ \\
\hline \multicolumn{13}{|c|}{$\begin{array}{l}\text { Nature of tested } \\
\text { factor }\end{array}$} \\
\hline Protein & $51(37)$ & $22(20)$ & $10(7)$ & $3(2)$ & $37(27)$ & 18 (17) & 0 & 0 & $2(1)$ & $1(1)$ & $2(2)$ & 0 \\
\hline DNA & $18(14)$ & $7(7)$ & $6(5)$ & $2(2)$ & $11(8)$ & $5(5)$ & $1(1)$ & 0 & 0 & 0 & 0 & 0 \\
\hline Antibody & $5(5)$ & $1(1)$ & $1(1)$ & 0 & $2(2)$ & 0 & $1(1)$ & 0 & 0 & 0 & $1(1)$ & $1(1)$ \\
\hline \multicolumn{13}{|l|}{$\begin{array}{l}\text { Method of } \\
\text { identification }\end{array}$} \\
\hline IHC & $49(35)$ & $21(19)$ & $9(6)$ & $2(1)$ & $36(26)$ & $18(17)$ & 0 & 0 & $2(1)$ & $1(1)$ & $2(2)$ & 0 \\
\hline MB & 18 (14) & $7(7)$ & $6(5)$ & $2(2)$ & $11(8)$ & $5(5)$ & $1(1)$ & 0 & 0 & 0 & 0 & 0 \\
\hline ELISA, blot. & $7(7)$ & $2(2)$ & $2(2)$ & $1(1)$ & $3(3)$ & 0 & $1(1)$ & 0 & 0 & 0 & $1(1)$ & $1(1)$ \\
\hline
\end{tabular}

Data are presented as $\mathrm{n}$ (number of studies evaluated for the meta-analysis). S: number of studies identifying p53 positivity as a statistically significant poor prognostic factor; IHC: immunohistochemistry; MB: molecular biology; blot.: blotting; DNA: deoxyribonucleic acid; NSCLC: nonsmall cell lung cancer; SCLC: small cell lung cancer. ELISA: enzyme-linked immunosorbent assay. 
they, therefore, could not be taken into account for the aggregation of the survival results. The reasons for noninclusion of a study into the meta-analysis were: absence of univariate analysis $(n=3)[37,63,80]$; no p-value, HR or CI reported $(n=8)[11,23,24,49,61$, $62,67,91]$; no survival curve shown $(\mathrm{n}=5)[17,31,35$, $53,81]$; no p53 status distribution $(n=2)[28,73]$.

\section{Study results report}

As shown in table 1,30 of the 74 trials (41\%) identified p53 abnormalities as a poor prognostic factor for survival (with 28 evaluated for the metaanalysis), $42(57 \%)$ concluded that p53 is not a prognostic factor for survival (26 evaluated), and two $(2 \%)$ reported a better prognosis for p53 positivity, both being evaluated $[18,58]$. In order to compare positive studies (p53 was statistically a poor prognostic factor) and negative studies (not statistically significant), the latter two studies were pooled with the negative ones.

Among the 67 trials on NSCLC, $28(42 \%)$ were positive (26 of which were evaluated). None of the two studies dealing with SCLC reported significant results. One of the two trials assessing p53 in neuroendocrine tumours had significant results. Three studies evaluated lung cancer of any histology and of any stage, of which one was significant. Twenty-two of the 51 trials $(43 \%)$ evaluating the role of p53 protein, $39 \%$ of those evaluating p53 DNA and $20 \%$ of those assessing antip53 antibodies, were significant.

Concerning the meta-analysis, 18 of the 74 studies were not evaluated. The evaluation status for the meta-analysis was associated with trial positivity; the rate of positive results was $50 \%$ for the trials that could be evaluated ( 28 of 56 ) compared to $11 \%$ ( 2 of 18) for those that could not $(\mathrm{p}=0.005)$.

\section{Quality assessment}

Overall, the global quality score ranged $23.9-85.2 \%$, with a median of $54.8 \%$ (table 2). The design subscore had the lowest value, with a median value of 4 out of 10 . The most poorly described items $(<30 \%$ of the maximum theoretical score) were the a priori estimate of sample size required to conduct the study $(2 \%)$, the blinding in evaluation of the results $(24 \%)$, and the initial workup description (11\%).

There was a significant correlation between the global score and the number of patients included in the study (Spearman correlation coefficient $r_{s}=0.43$, $\mathrm{p}=0.0015)$.

Concerning the global score, there was no statistically significant difference between the 30 positive and the 44 negative trials (median of $55.1 \%$ versus $54.3 \%$, $\mathrm{p}=0.24$ by the Mann-Whitney U-test). However, the positive trials had a better score concerning the report of the analysis results: 6.2 of 10 in comparison to 3.7 of 10 for the negative trials $(\mathrm{p}=0.02)$.

There was no statistically significant difference between the 56 studies that were evaluated and the 18 studies that were not, either for the global score $(54.8 \%$ in comparison to $54.6 \%, \mathrm{p}=0.72$ by the MannWhitney U-test) or the four subscores.

Concerning the 56 trials evaluated for the metaanalysis, the global score ranged $24.0-85.2 \%$, with a median of $54.8 \%$. The four subscores were superimposable to those of the 74 trials, with the design subscore being the worst described. The same items were poorly described $(<30 \%$ of maximal theoretical score). There was no significant difference between the positive and the negative trials according to the global score (median of $54.8 \%$ in both groups, $\mathrm{p}=0.61$ ).

The global score was not statistically different between studies assessing p53 status by IHC $(n=35)$ or by molecular biology $(n=14)$, with scores of $56.5 \%$ and $52.4 \%$, respectively $(\mathrm{p}=0.07)$, but there was a significant difference for the description of the laboratory methodology, IHC being better described than molecular biology (6.4 of 10 compared to 4 of 10 , $\mathrm{p}=0.0002$ ).

\section{Meta-analysis}

The absence of a significant difference in the overall methodology score between the positive and negative trials led to the performance of the quantitative aggregation of the individual survival results. Because of the important heterogeneity of the cohorts of the 56 selected trials, only subgroup analyses were

Table 2. - Results of the methodological assessment by the European Lung Cancer Working Party score

\begin{tabular}{|c|c|c|c|c|c|c|}
\hline & Studies n & $\begin{array}{l}\text { Global } \\
\text { score \% }\end{array}$ & Design* & $\begin{array}{l}\text { Laboratory } \\
\text { methodology* }\end{array}$ & Generalizability* & $\begin{array}{c}\text { Results } \\
\text { analysis* }\end{array}$ \\
\hline All studies & 74 & 54.8 & 4.0 & 5.7 & 6.7 & 5.6 \\
\hline Evaluated for the MA & 56 & 54.8 & 4.0 & 5.7 & 6.6 & 5.6 \\
\hline Not evaluated for the MA & 18 & 54.6 & 4.5 & 5.7 & 6.6 & 5.0 \\
\hline p-value & & 0.72 & 0.83 & 0.89 & 0.81 & 0.16 \\
\hline Positive & 30 & 55.1 & 4.4 & 6.4 & 6.6 & 6.2 \\
\hline Negative & 44 & 54.3 & 4.0 & 5.7 & 6.6 & 3.7 \\
\hline $\mathrm{p}$-value & & 0.24 & 0.57 & 0.49 & 0.94 & 0.02 \\
\hline IHC & 35 & 56.5 & 4.0 & 6.4 & 6.6 & 6.2 \\
\hline MB & 14 & 52.4 & 4.0 & 4.0 & 6.6 & 5.6 \\
\hline $\mathrm{p}$-value & & 0.07 & 0.31 & 0.0002 & 0.29 & 0.88 \\
\hline
\end{tabular}

Score distributions are summarized by the median values. $*$ : score out of 10 . Positive: studies identifying p53 positivity as significant poor prognostic factor for survival; Negative: studies reporting nonsignificant results or identifying p53 positivity as associated with better survival; IHC: immunohistochemistry; MB: molecular biology; MA: meta-analysis. 
performed. Indeed, authors report on different patient cohorts (selected on the basis of histology, stage and/or treatment). Furthermore, the techniques used to identify p53 abnormalities could bring some additional heterogeneity.

The subgroups that were analysed were defined according to the covariates described earlier.

Of the 56 evaluable studies, eight were not used in the meta-analysis for the following reasons. Results aggregation was not performed in SCLC because the approaches used by the two available studies were too different, one assessed the p53 gene directly into the tumour cell [60] and the other assessed circulating anti-p53 antibodies [82]. For neuroendocrine tumours there was only one trial that could be evaluated [77]. Of the three studies including any type of lung cancer, one reported results for the subgroups of adenocarcinomas and squamous cell carcinomas [64], which were used in their respective classes. The other two analysed p53 using very different approaches that prevented them from being aggregated together; one assessed the protein into the tumour cell [19] and the other circulating antibodies [54].

The five studies assessing circulating anti-p53 antibodies that could be evaluated were not aggregated because they all dealt with different patient populations: any stage of NSCLC [18], locoregional squamous cell lung cancer [50], SCLC [82], and any type of lung cancer [54].

The individual HRs of the 48 evaluated studies were calculated by one of the three methods reported in the Materials and methods section. Only five studies reported the data needed to directly calculate the estimated HR. In 14 trials, HR was approximated by the total number of events and the logrank statistic or its p-value. For the 29 remaining studies, HR had to be extrapolated from the graphical representations of the survival distributions.

Stages I and II NSCLC subgroup included 19 trials (nine positive) analysing 2,580 patients. The aggregation produced a statistically significant HR $(1.52 ; 95 \%$ CI 1.35-1.72) with a worse survival prognosis in cases of p53 abnormalities (table 3). The test for heterogeneity gave a significant result $(\mathrm{p}=0.01)$, but it was not possible to go further in the categorization of the trials, and namely, to treat papers reporting on Stage I patients separately. The use of a random-effects model did not change the conclusion with a combined HR of 1.78 (95\% CI 1.45-2.19).

The surgically resected NSCLC subgroup, defined as a tumour completely surgically resected without any other treatment modality, with 10 positive trials among 20, showed very similar results $(\mathrm{HR}=1.56$; 95\% CI 1.37-1.79, Chi-squared test for heterogeneity $\mathrm{p}=0.02$ ) (table 4). Once again, the introduction of a random effect did not change the interpretation of the $\mathrm{HR}(\mathrm{HR}=1.66 ; 95 \%$ CI 1.37-2.01).

Studies performed in NSCLC Stages I-IIIB, or Stages III and IV, or all stages (trials 5, 9 and 11 respectively) also showed HR to be significantly $>1$ by the aggregation: 1.68 (95\% CI 1.23-2.29), 1.68 (95\% CI $1.30-2.18)$ and $1.44(95 \%$ CI $1.20-1.72)$ respectively. No heterogeneity was detectable in any of these subgroups $(\mathrm{p}>0.05)$ (tables 5-7).

Table 3.-Meta-analysis of the studies including stages I and II nonsmall cell lung cancer (NSCLC), with their characteristics

\begin{tabular}{|c|c|c|c|c|c|c|}
\hline First author [ref. no.] & Method & QS \% & Patients $n$ & $\mathrm{p} 53+\%$ & $\mathrm{HR}$ & $95 \% \mathrm{CI}$ \\
\hline CHEN [21] & IHC-DO-7 & 33 & 40 & 68 & 0.40 & $0.00 *$ \\
\hline D'AMICO [9] & IHC & 76 & 408 & 43 & 1.72 & $1.25-2.38$ \\
\hline HARPOLE [39] & IHC-1801 & 75 & 138 & 36 & 2.36 & $1.29-4.30$ \\
\hline HARPOLE [40] & IHC-1801 & 85 & 275 & 40 & 1.56 & $1.15-2.11$ \\
\hline HORIO [42] & PCR-SSCP & 52 & 48 & 48 & 3.60 & $1.42-9.10$ \\
\hline KAWASAKI [47] & IHC & 43 & 200 & 53 & 3.45 & $1.49-7.99$ \\
\hline KAWASAKI [48] & IHC & 55 & 41 & 46 & 1.20 & $0.35-4.09$ \\
\hline KONDO [51] & RT-PCR-SSCP & 33 & 23 & 56 & 0.58 & $0.08-4.27$ \\
\hline KONISHI [52] & IHC-DO-7 & 49 & 105 & 49 & 4.10 & $1.68-9.98$ \\
\hline LEVESQUE [59] & ELISA & 63 & 68 & 48 & 3.05 & $0.93-10.00$ \\
\hline MITSUDOMI [65] & PCR-SSCP & 53 & 58 & 41 & 1.55 & $0.70-3.44$ \\
\hline MOLDVAY [68] & IHC & 45 & 83 & 55 & 2.54 & $1.22-5.29$ \\
\hline NisHiO [71] & IHC-DO-7 & 63 & 79 & 37 & 1.47 & $0.66-3.25$ \\
\hline OHSAKI [74] & IHC-DO-7 & 54 & 46 & 41 & 1.62 & $0.58-4.51$ \\
\hline РАРPOT [75] & ELISA & 56 & 131 & 50 & 1.22 & $0.75-1.97$ \\
\hline PASTORINO [76] & IHC-DO-7 & 76 & 515 & 43 & 0.98 & $0.78-1.24$ \\
\hline QUINLAN [79] & IHC-1801 & 52 & 114 & 43 & 2.01 & $0.97-4.19$ \\
\hline TOMIZAWA [86] & PCR-SSCP & 55 & 108 & 41 & 2.25 & $1.12-4.51$ \\
\hline XU [92] & IHC & 57 & 119 & 45 & 1.81 & $1.09-3.00$ \\
\hline \multicolumn{7}{|l|}{ Overall } \\
\hline Fixed-effects model & & 55 & 2580 & 43 & 1.52 & $1.35-1.72$ \\
\hline Random-effects model & & & & & 1.78 & $1.45-2.19$ \\
\hline
\end{tabular}

*: not possible to calculate. QS: quality score; p53+: presence of an abnormality of p53; HR: hazard ratio; CI: confidence interval; IHC: immunohistochemistry with antibodies other than DO-7 or 1801; IHC-DO-7: immunohistochemistry with monoclonal antibody DO-7; IHC-1801: immunohistochemistry with monoclonal antibody 1801; RT: reverse transcription; PCR: polymerase chain reaction; SSCP: single-strand conformation polymorphism method; ELISA: enzyme-linked immunosorbent assay technique. For group of NSCLC stages I-II, n=19. Chi-squared statistic for heterogeneity=35.47, 18 degrees of freedom, $\mathrm{p}=0.01$. 
Table 4.-Meta-analysis of the studies including surgical stage nonsmall cell lung cancer (NSCLC), with their characteristics

\begin{tabular}{|c|c|c|c|c|c|c|}
\hline First author [ref. no.] & Method & QS \% & Patients $\mathrm{n}$ & $\mathrm{p} 53+\%$ & HR & $95 \% \mathrm{CI}$ \\
\hline CARBONE [20] & PCR-SSCP & 52 & 85 & 53 & 0.88 & $0.46-1.67$ \\
\hline DALQUEN [22] & IHC & 54 & 215 & 47 & 1.37 & $0.99-1.89$ \\
\hline EBINA [26] & IHC-DO-7 & 55 & 138 & 36 & 3.55 & $1.54-8.22$ \\
\hline ESPOSITO [27] & IHC-DO-7 & 53 & 61 & 36 & 2.15 & $1.06-4.38$ \\
\hline FONTANINI [29] & IHC-1801 & 57 & 48 & 48 & 2.63 & $1.29-5.38$ \\
\hline FONTANINI [30] & IHC-1801 & 52 & 107 & 50 & 2.02 & $1.07-3.82$ \\
\hline FUJINO [32] & IHC-DO-7 & 70 & 63 & 57 & 1.80 & $0.99-3.25$ \\
\hline GERADTS [34] & IHC-DO-7 & 52 & 103 & 49 & 0.83 & $0.49-1.42$ \\
\hline HORIO [42] & PCR-SSCP & 52 & 71 & 49 & 2.45 & $1.32-4.55$ \\
\hline ISHIDA [45] & IHC-DO-7 & 72 & 114 & 39 & 2.30 & $0.56-9.19$ \\
\hline KIM [10] & IHC & 79 & 62 & $\mathrm{NC}$ & 0.90 & $0.30-2.70$ \\
\hline LAUDANSKI [56] & IHC-DO-7 & 78 & 84 & 55 & 2.69 & $1.31-5.52$ \\
\hline LAVEZZI [57] & IHC-1801 & 52 & 152 & 16 & 1.25 & $0.69-2.26$ \\
\hline LEE [58] & IHC-DO-7 & 63 & 156 & 65 & 1.06 & $0.61-1.84$ \\
\hline MOLDVAY [68] & IHC & 45 & 83 & 55 & 2.54 & $1.22-5.29$ \\
\hline MORKVE [69] & IHC-1801 & 57 & 112 & 77 & 1.41 & $0.74-2.70$ \\
\hline NISHIO [71] & IHC-DO-7 & 63 & 208 & 46 & 1.08 & $0.73-1.60$ \\
\hline TOP [88] & PCR-DGGE & 46 & 46 & 67 & 2.51 & $0.96-6.56$ \\
\hline TORMANEN [89] & IHC & 49 & 71 & 52 & 2.41 & $1.40-4.16$ \\
\hline VEGA [90] & PCR-SSCP & 63 & 62 & 26 & 3.02 & $1.05-8.68$ \\
\hline \multicolumn{7}{|l|}{ Overall } \\
\hline Fixed-effects model & & 54 & 2041 & 48 & 1.56 & $1.37-1.79$ \\
\hline Random-effects model & & & & & 1.66 & $1.37-2.01$ \\
\hline
\end{tabular}

QS: quality score; p53+: presence of an abnormality of p53; HR: hazard ratio; CI: confidence interval; PCR: polymerase chain reaction; SSCP: single-strand conformation polymorphism method; IHC: immunohistochemistry with antibodies other than DO-7 or 1801; IHC-DO-7: immunohistochemistry with monoclonal antibody DO-7; IHC-1801: immunohistochemistry with monoclonal antibody 1801; DGGE: denaturing gradient gel electrophoresis. For group of NSCLC, surgically resected $\mathrm{n}=20$. Chi-squared statistic for heterogeneity $=33.82,19$ degrees of freedom, $\mathrm{p}=0.02$.

When considering the NSCLC histological subtypes, nine trials were assessable for adenocarcinoma (table 8) and nine for squamous cell carcinoma (table 9). Results were significant, with an HR of $2.24(95 \%$ CI $1.70-2.95)$ and 1.37 (95\% CI 1.02-1.85) respectively, without any significant heterogeneity.

The methodology used to detect p53 abnormalities was analysed according to the following three aggregations (figs. 1-3, individual data having been already reported in previous tables): IHC with antibody $1801(n=8)$, IHC with antibody DO-7 $(n=16)$ and molecular biology $(\mathrm{n}=13)$. HRs were $1.57(95 \%$ CI $1.28-1.91), 1.25(95 \%$ CI $1.09-1.43)$ and 1.65 (95\% CI 1.35-2.00) respectively. The three corresponding Chi-squared tests for heterogeneity were not statistically significant $(\mathrm{p}=0.38, \mathrm{p}=0.77$ and $\mathrm{p}=0.32$, respectively).

\section{Discussion}

The systematic review of the literature shows that alteration of the p53 gene in the lung cancer cells is a poor prognostic factor for survival in patients with NSCLC. The analysis revealed similar features for each NSCLC subgroup and helped to clarify the somewhat inconsistent message of individual studies.

This observation is potentially important for prognostic reasons. Identification of independent prognostic factors allowed for the definition of high-risk

Table 5.-Meta-analysis of the studies including Stages I-IIIA nonsmall cell lung cancer (NSCLC), with their characteristics

\begin{tabular}{|c|c|c|c|c|c|c|}
\hline First author [ref. no.] & Method & QS \% & Patients $\mathrm{n}$ & $\mathrm{p} 53+\%$ & HR & $95 \% \mathrm{CI}$ \\
\hline CHEN [21] & IHC-DO-7 & 33 & 40 & 68 & 0.40 & $0.00 *$ \\
\hline DOSAKA-AKITA [25] & IHC-DO-7 & 57 & 44 & 50 & 2.12 & $0.76-5.90$ \\
\hline HUANG [43] & PCR-SSCP & 58 & 168 & 55 & 1.42 & $0.86-2.32$ \\
\hline KONDO [51] & RT-PCR-SSCP & 33 & 42 & 43 & 1.46 & $0.45-4.70$ \\
\hline TANAKA [85] & IHC-DO-7 & 71 & 236 & 39 & 1.90 & $1.19-3.04$ \\
\hline Overall & & 57 & 530 & 45 & 1.68 & $1.23-2.30$ \\
\hline
\end{tabular}

*: not possible to calculate. QS: quality score; p53+: presence of an abnormality of p53; HR: hazard ratio; CI: confidence interval; IHC-DO-7: immunohistochemistry with monoclonal antibody DO-7; PCR: polymerase chain reaction; SSCP: singlestrand conformation polymorphism method; RT: reverse transcription. Group of NSCLC Stages I-IIIB, n=5. Chi-squared statistic for heterogeneity $=0.99,4$ degrees of freedom, $\mathrm{p}=0.91$. 
Table 6.-Meta-analysis of the studies including stages III and IV nonsmall cell lung cancer (NSCLC), with their characteristics

\begin{tabular}{|c|c|c|c|c|c|c|}
\hline First author [ref. no.] & Method & QS \% & Patients $n$ & $\mathrm{p} 53+\%$ & HR & $95 \% \mathrm{CI}$ \\
\hline HAYAKAWA [41] & IHC-DO-7 & 58 & 22 & 77 & 0.64 & $0.09-4.39$ \\
\hline KANDIOLER-ECKERSBERGER [46] & PCR-sequencing & 54 & 24 & 33 & 3.58 & $0.98-13.00$ \\
\hline KAWASAKI [48] & IHC & 55 & 70 & 60 & 1.60 & $0.99-2.60$ \\
\hline KONDO [51] & RT-PCR-SSCP & 33 & 19 & 26 & 4.72 & $1.22-18.29$ \\
\hline LANGENDIJK [55] & IHC-DO-7 & 69 & 65 & 57 & 1.25 & $0.73-2.16$ \\
\hline LEVESQUE [59] & ELISA & 63 & 17 & 53 & 4.42 & $0.80-24.43$ \\
\hline MITSUDOMI [65] & PCR-SSCP & 53 & 62 & 44 & 2.30 & $1.22-4.32$ \\
\hline MURAKAMI [70] & PCR-DGGE & 63 & 32 & 28 & 2.24 & $0.92-5.44$ \\
\hline NiSHIO [71] & IHC-DO-7 & 63 & 21 & 38 & 0.92 & $0.43-1.98$ \\
\hline Overall & & 58 & 332 & 44 & 1.68 & $1.30-2.18$ \\
\hline
\end{tabular}

QS: quality score; p53+: presence of an abnormality of p53; HR: hazard ratio; CI: confidence interval; IHC-DO-7: immunohistochemistry with monoclonal antibody DO-7; PCR: polymerase chain reaction; IHC: immunohistochemistry with antibodies other than DO-7 or 1801; RT: reverse transcription; ELISA: enzyme-linked immunosorbent assay technique; SSCP: single-strand conformation polymorphism method; DGGE: denaturing gradient gel electrophoresis. Group of NSCLC Stages III-IV, $\mathrm{n}=9$. Chi-squared statistic for heterogeneity $=10.61,8$ degrees of freedom, $\mathrm{p}=0.22$.

Table 7.-Meta-analysis of studies including nonsmall cell lung cancer (NSCLC) of any stage, with their characteristics

\begin{tabular}{|c|c|c|c|c|c|c|}
\hline First author [ref. no.] & Method & QS \% & Patients $n$ & $\mathrm{p} 53+\%$ & HR & $95 \% \mathrm{CI}$ \\
\hline FUJINO [32] & IHC-DO-7 & 70 & 91 & 58 & 1.71 & $1.05-2.78$ \\
\hline GREATENS [36] & PCR-SSCP & 55 & 101 & 40 & 1.81 & $1.00-3.26$ \\
\hline HAYAKAWA [41] & IHC-DO-7 & 58 & 36 & 69 & 1.55 & $0.51-4.71$ \\
\hline KIM [10] & $\mathrm{IHC}$ & 79 & 238 & 18 & 1.00 & $0.55-1.82$ \\
\hline LEVESQUE [59] & ELISA & 63 & 71 & 48 & 2.47 & $1.03-5.92$ \\
\hline MITSUDOMI [65] & PCR-SSCP & 53 & 120 & 43 & 1.92 & $1.17-3.15$ \\
\hline MURAKAMI [70] & PCR-DGGE & 63 & 54 & 39 & 1.12 & $0.60-2.08$ \\
\hline OHSAKI [74] & IHC-DO-7 & 54 & 99 & 44 & 1.47 & $0.91-2.37$ \\
\hline QUANTIN [78] & IHC-1801 & 71 & 89 & 52 & 0.85 & $0.46-1.60$ \\
\hline TAGAWA [83] & PCR-SSCP & 24 & 67 & 34 & 1.44 & $0.59-3.52$ \\
\hline $\mathrm{XU}[92]$ & IHC & 57 & 66 & 56 & 1.30 & $0.79-2.13$ \\
\hline Overall & & 58 & 1032 & 44 & 1.44 & $1.20-1.72$ \\
\hline
\end{tabular}

QS: quality score; p53+: presence of an abnormality of p53; HR: hazard ratio; CI: confidence interval; IHC-DO-7: immunohistochemistry with monoclonal antibody DO-7; PCR: polymerase chain reaction; SSCP: single-strand conformation polymorphism method; DGGE: denaturing gradient gel electrophoresis; IHC-1801: immunohistochemistry with monoclonal antibody 1801; IHC: immunohistochemistry with antibodies other than DO-7 or 1801; ELISA: enzyme-linked immunosorbent assay. Group of NSCLC all stages, $n=11$. Chi-squared statistic for heterogeneity $=8.70,10$ degrees of freedom, $\mathrm{p}=0.56$.

Table 8. - Meta-analysis of the studies assessing adenocarcinoma, with their characteristics

\begin{tabular}{|c|c|c|c|c|c|c|}
\hline First author [ref. no.] & Method & QS \% & Patients $\mathrm{n}$ & $\mathrm{p} 53+\%$ & HR & $95 \% \mathrm{CI}$ \\
\hline DOSAKA-AKITA [25] & IHC-DO-7 & 57 & 44 & 50 & 2.12 & $0.76-5.90$ \\
\hline FUKUYAMA [33] & PCR-SSCP & 46 & 94 & 27 & 2.74 & $1.20-6.26$ \\
\hline HARPOLE [39] & IHC-1801 & 75 & 138 & 36 & 2.36 & $1.29-4.30$ \\
\hline HUANG [43] & PCR-SSCP & 58 & 125 & 26 & 1.71 & $0.94-3.14$ \\
\hline ISHIDA [45] & IHC-DO-7 & 72 & 114 & 39 & 2.30 & $0.58-9.19$ \\
\hline KAWASÄKI [47] & IHC & 43 & 200 & 27 & 3.45 & $1.49-7.99$ \\
\hline KONISHI [52] & IHC-DO-7 & 49 & 105 & 49 & 4.10 & $1.68-9.98$ \\
\hline LEVESQUE [59] & ELISA & 63 & 43 & 56 & 2.07 & $0.69-6.21$ \\
\hline MCLAREN [64] & IHC & 46 & 42 & 50 & 1.09 & $0.46-2.59$ \\
\hline Overall & & 57 & 905 & 39 & 2.24 & $1.70-2.95$ \\
\hline
\end{tabular}

QS: quality score; p53+: presence of an abnormality of p53; HR: hazard ratio; CI: confidence interval; IHC-DO-7: immunohistochemistry with monoclonal antibody DO-7; IHC-1801: immunohistochemistry with monoclonal antibody 1801; PCR: polymerase chain reaction; SSCP: single-strand conformation polymorphism method; IHC: immunohistochemistry with antibodies other than DO-7 or 1801; ELISA: enzyme-linked immunosorbent assay. Group of adenocarcinoma, $\mathrm{n}=9$. Chi-squared statistic for heterogeneity $=6.49,8$ degrees of freedom, $\mathrm{p}=0.59$. 
Table 9. - Meta-analysis of the studies assessing squamous cell carcinoma with their characteristics

\begin{tabular}{llccccc}
\hline First author [ref. no.] & Method & QS $\%$ & Patients n & p53+\% & HR & 95\% CI \\
\hline CHEN [21] & IHC-DO-7 & 33 & 40 & 68 & 0.40 & $0.00-\mathrm{NC}$ \\
FUKUYAMA [33] & PCR-SSCP & 46 & 57 & 46 & 0.74 & $0.24-2.31$ \\
HUANG [43] & PCR-SSCP & 58 & 71 & 48 & 1.33 & $0.54-3.26$ \\
LEVESQUE [59] & ELISA & 63 & 37 & 46 & 4.64 & $0.91-23.67$ \\
MCLAREN [64] & IHC & 46 & 77 & 56 & 1.07 & $0.47-2.32$ \\
MOLDVAY [68] & IHC & 45 & 80 & 54 & 2.54 & $1.22-5.29$ \\
NiSHIO [71] & IHC-DO-7 & 63 & 88 & 52 & 0.98 & $0.52-1.84$ \\
TORMANEN [89] & IHC & 49 & 47 & 53 & 3.10 & $1.15-8.31$ \\
VEGA [90] & PCR-SSCP & 63 & 21 & 38 & 0.92 & $0.43-1.98$ \\
Overall & & 49 & 518 & 52 & 1.37 & $1.02-1.85$ \\
\hline
\end{tabular}

QS: quality score; p53+: presence of an abnormality of p53; HR: hazard ratio; CI: confidence interval; IHC-DO-7: immunohistochemistry with monoclonal antibody DO-7; IHC: immunohistochemistry with antibodies other than DO-7 or 1801; PCR: polymerase chain reaction; SSCP: single-strand conformation polymorphism method; ELISA: enzyme-linked immunosorbent assay. Group of squamous cell carcinoma, n=9. Chi-squared statistic for heterogeneity=11.13, 8 degrees of freedom, $\mathrm{p}=0.19$.

groups of patients for whom specific therapy could be designed or a stratification in randomized trials performed. So far, for lung cancer, useful prognostic factors are clinical variables, such as disease extent or performance status, or routine histological tests, such as white blood cell count or serum lactate dehydrogenase level. The results of the meta-analysis, which suggested a relationship between p53 and survival but only in a univariate setting, should encourage the development of adequately designed prospective studies, with an appropriate statistical methodology including multivariate analysis, in order to demonstrate the routine utility of a molecular biology marker like $\mathrm{p} 53$.

Moreover, the presence of abnormal p53 expression might be a potential therapeutic target. Tumour suppressor gene therapy is currently the topic of preliminary clinical investigations [93, 94].

The aggregation of the survival data was performed by using the results reported in the univariate analysis only. The type of studies available were very heterogeneous, often oriented to particular groups of

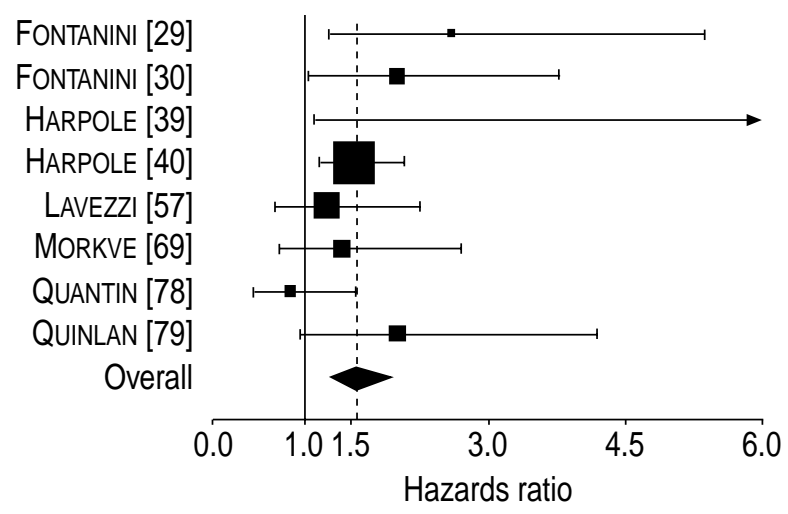

Fig. 1.- Results of the meta-analysis of the studies evaluating p53 status by immunohistochemistry with antibody 1801 . Hazard ratio $>1$ implies a worse survival for the group with p53 abnormalities. 口: hazard ratio value of each study, designed proportionally to the amount of patients included; - - - : combined hazard ratio of the meta-analysis of the studied subgroup; $\diamond$ : the centre of the diamond gives the combined hazard ratio and its extremities the $95 \%$ confidence interval. patients, such as those with NSCLC treated by surgery alone or with a specific histological subtype or a particular tumour stage. For this reason, a global meta-analysis was not performed and the analysis concentrated on more homogeneous subgroups of patients by aggregating the data of studies conducted in similar patient populations or tumours.

Even by doing this, however, the issue of heterogeneity existing among the individual trials could not be addressed completely. Indeed, in two of the 10 subgroups considered, a statistically significant test for heterogeneity was found (Stages I-II and surgical stages). In the subgroup of Stages I-II, the heterogeneity was mostly due to a particular study [76],

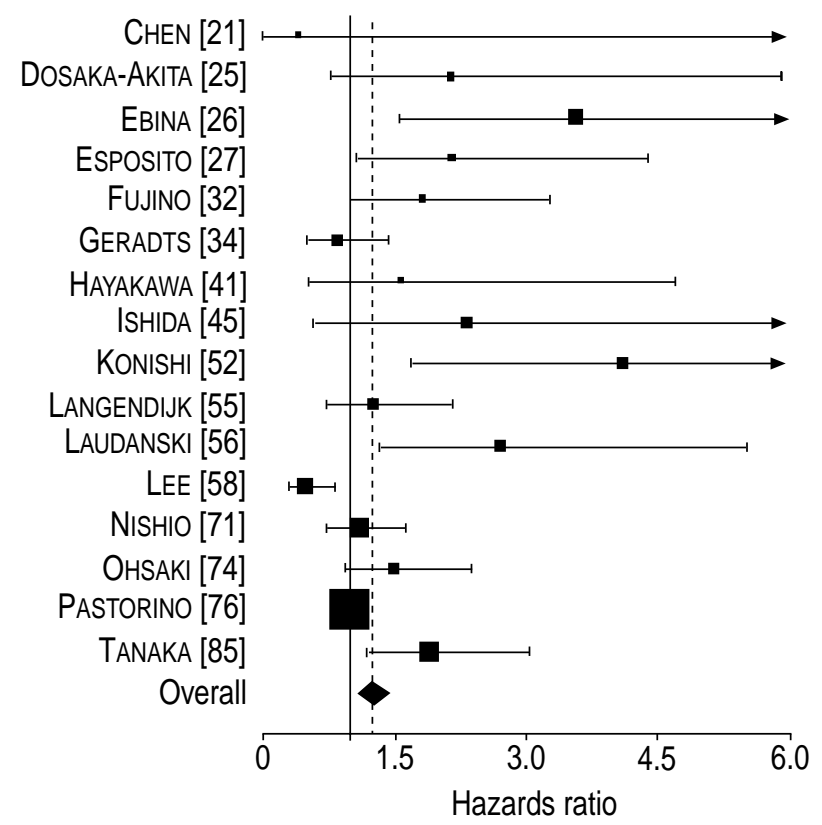

Fig. 2.- Results of the meta-analysis of the studies evaluating p53 status by immunohistochemistry with antibody DO-7. $\mathbf{\square}$ : hazard ratio value of each study, designed proportionally to the amount of patients included; - - - : combined hazard ratio of the metaanalysis of the studied subgroup; $\diamond$ : the centre of the diamond gives the combined hazard ratio and its extremities the $95 \%$ confidence interval. 


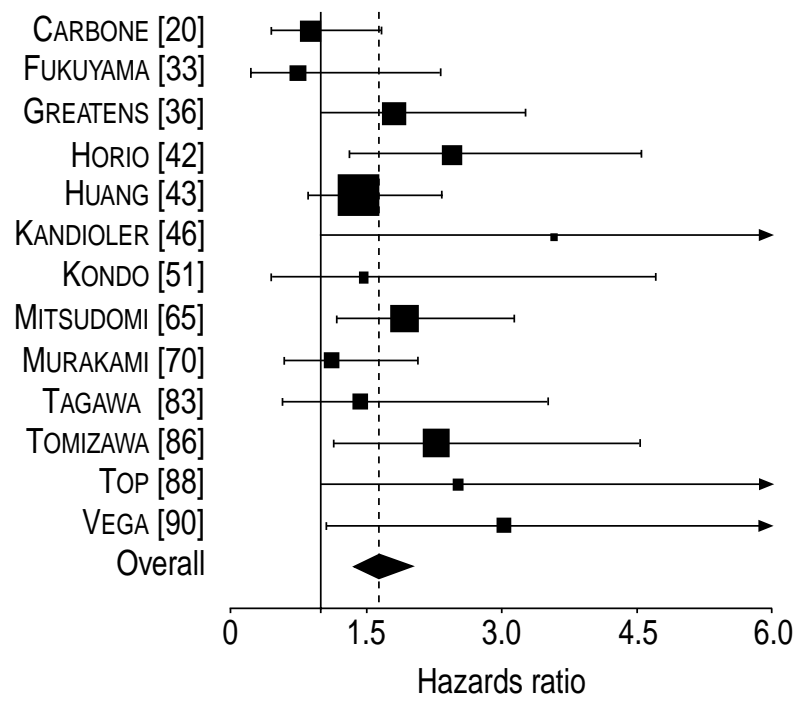

Fig. 3.-Results of the meta-analysis of the studies evaluating p53 status by molecular biology. $\boldsymbol{\square}$ : hazard ratio value of each study, designed proportionally to the amount of patients included; - - - : combined hazard ratio of the meta-analysis of the studied subgroup; $\diamond$ : the centre of the diamond gives the combined hazard ratio and its extremities the $95 \%$ confidence interval.

which was dedicated to pathological Stage I patients only. By dropping this trial, the test for heterogeneity became unsignificant $(\mathrm{p}=0.51)$. The selection of patients with the best possible prognosis, such as Stage I disease, might be responsible for the lack of effect of p53 abnormality on survival. However, no other trial provided results specific to Stage I patients, and it was thus impossible to analyse them separately.

In the surgically resected subgroup, the detected heterogeneity was less surprising. Patient candidates with the most favourable prognosis for surgery might belong to Stage I, with a seriously decreased probability of survival for Stage IIIA. The definition of this subgroup, using the treatment covariate, was not optimal, but categorization according to covariates having a better prognostic value was not possible because of the lack of available data in the publications.

When using random-effects models, the authors came to the same conclusion as with fixed-effects models, but such models do not identify the source of heterogeneity, which is the important clinical point. However, the quantitative aggregated HRs were consistent and similar in all the categories tested, with significantly decreased survival in cases of abnormally expressed p53 protein or gene mutation: Stages I-II NSCLC, NSCLC treated by surgery, Stages I-IIIB NSCLC, Stage III-IV NSCLC, any stage NSCLC, adenocarcinoma, squamous cell carcinoma (tables 3-9). Subgroups of studies dealing with neuroendocrine tumours, SCLC, any histology and antibodies antip53 were not meta-analysed because of the lack of similar approaches.

It should be noted that the two eligible studies reporting on SCLC were both negative. The single trial assessing the gene directly [60] included a very small number of patients $(n=28)$ and the information provided therefore has to be considered as preliminary.
In fact, further studies are necessary to determine the value of p53 as a prognostic factor for survival in SCLC.

The decision to perform the meta-analysis was based on a prior methodological quality assessment of the publications. A methodology similar to that of previous systematic reviews reported by the present authors on the treatment of lung cancer was used [95-98]. A specific scale for biological prognostic factors was designed (Appendix) based on the opinion of experts and on prior experience in the field. By comparing the scores of the studies where p53 was a significant prognostic factor and of those where it was not, differences could be identified that suggested biases induced by the trials methodology. In fact, the comparison of the scores of the two groups showed no statistically significant difference, allowing for a meaningful data aggregation. It should be stressed, however, that results analysis was significantly better reported in the positive studies than in the negative studies.

However, the methodology used did not prevent all of the potential biases. The most important one is probably the publication bias. Indeed, studies with nonstatistically significant results are published less often or, if they are, with more concise data (as shown in the methodological analysis). Moreover, there is a language problem. The present review was restricted to articles published in English and French because other languages such as Japanese were not accessible for the readers. This bias could favour the positive studies that are more often published in English, while the negative ones tend to be reported in native languages [99]. Another possible source of confusion is the use of the same cohort of patients for different publications $[39,43,72,84,86]$ and it might be difficult to avoid the fact that the same patients have been included twice or three times in the metaanalysis. Finally, for practical purposes because of their small number, the two trials that showed a significant positive survival effect of the presence of abnormal p53 were included in the negative group.

The diversity in the techniques used to identify alteration of the p53 status can also be a potential source of bias. Some authors search for mutations inside the gene by molecular biology techniques, usually by targeting exons 5-8 where the majority of mutations in lung cancer are situated [100]. However, not all mutated proteins lose their physiological function and in the case of p53, the disturbance of the regulation of the cell cycle depends on the site of the mutation [101, 102]. Moreover, not all mutations are found by a partial analysis of the gene. Other authors have studied the accumulation of an abnormal form of the protein in the cell nucleus, the normal p53 protein having a half-life that was too short to be detected [103]. For that purpose they used an immunohistochemistry technique or, less often, ELISA. Immunohistochemistry is not performed with the same antibody to reveal the protein. Moreover, the cut-off in the number of positive cells defining a tumour with p53 accumulation is often arbitrary and varies according to the investigators, from a few per cent to $50 \%$. An optimal threshold is yet to be 
defined. Sometimes, the manipulations might be inadequate: for example, the use of the antibody 1801 on a paraffin-embedded tissue, because of its specific immunoreactivity [104], or the absence of prior reaction of epitope unmasking on fixed tissue [105]. Finally, immunohistochemistry can produce false-negative results because some mutations are associated with the absence of detectable protein [106], or false-positive results because p53 can be quantitatively increased or stabilized in circumstances other than gene mutations [107-109]. Thus, there is no absolute correlation between immunohistochemistry and molecular biology. To try to exclude the technique bias, a subgroups analyses was performed according to the most frequently used methods: immunohistochemistry with antibody 1801, immunohistochemistry with antibody DO-7 and molecular biology (figs. 1-3). In any situation, the results were consistent, with poorer survival in cases where there was an abnormal p53 status, making the techniques improbable as a source of bias.

Some biases can be due to the methodology used to perform the meta-analysis. As already highlighted, the negative studies reported less detailed results, making them unlikely to be evaluated. Of 18 studies excluded for the meta-analysis due to a lack of reported data, 16 were negative, which represents a significantly higher proportion than in the trials evaluable for the meta-analysis. There is thus, a potential bias in favour of positive trials. Another potential source of biases is related to the method of extrapolation of the HR. If they were not reported by the authors, they were calculated from the data available in the article and, if this was not possible, they were extrapolated from the survival curves, hence making assumptions on the censoring process. Moreover, the choice of time intervals for reading mortality rates on the curves is not the object of a consensus. Finally, it should again be emphasized that a global meta-analysis did not appear meaningful because of the heterogeneity of the patient populations. This potential population bias makes it hazardous to generalize the results of the meta-analysis of subgroups of patients that were not included in the data aggregation, such as those with SCLC.

The present results are based on an aggregation of data obtained by univariate survival analysis in a majority of retrospective trials. It should be stressed that an HR of 1.5-2 does not mean a large effect of p53 on survival and, therefore, p53 does not constitute a useful factor for prediction of shorter survival at the level of individual patients. The results need to be confirmed by an adequately designed prospective study and the exact value of an abnormal p53 status needs to be determined by an appropriate multivariate analysis, taking into account the classical well-defined prognostic factors for lung cancer. A meta-analysis based on the individual data of the patients included into the studies [110] would help to define, by multivariate methods, the prognostic role of $\mathrm{p} 53$, but it will require the collection of a huge amount of retrospective data, with the potential problem of dealing with a lot of missing data. Moreover, it will not have the definitive value of a well-designed prospective study [111].

To conclude, a systematic review of the lung cancer literature suggested a poor prognostic value for survival of an abnormal p53 status in patients with nonsmall cell lung cancer, whatever the biological test used. Data are insufficient to determine its role in small cell lung cancer. This observation requires further investigation with an adequate statistical methodology to determine its exact place among the other known survival prognostic factors for lung cancer.

\section{Appendix: European Lung Cancer Working Party quality scale for biological prognostic factors for lung cancer}

Except when specified, the attributed value per item is 2 points if it is clearly defined in the article, 1 point if its description is incomplete or unclear and 0 point if it is not defined or is inadequate.

\section{Scientific design}

1. Study objective definition.

2. Study design: prospective (2 points); retrospective or retrolective (1 point); not defined (0 point).

3. Outcome definition.

4. Statistical considerations: fully reported with a preliminary assessment of the patient/sample number to be included and/or analysed (2 points); patient/sample number to be included and/or analysed justified by the number of studied variables (minimum 10 patients per variable) (1 point); not defined (0 point).

5. Statistical methods and tests description.

\section{Laboratory methodology}

1. Blinding in the biological assays performance: double-blind (2 points); simple-blind (1 point); unblinded or not defined (0 point).

2. Tested factor description: DNA (types of exons analysed), messenger RNA (complete or partial with description of the primers used), protein (nuclear, cytoplasmic or extracted from cellular components), antibodies (type of tissue or liquid sampled).

3. Tissue sample conservation: either fresh tissue or conservation requiring freezing at $\leqslant-80^{\circ} \mathrm{C}$ in presence of an anti-RNAase for RNA or freezing at $\leqslant-20^{\circ} \mathrm{C}$ for DNA, protein and serum, or fixation in formol, alcohol or paraffin.

4. Description of the revelation test procedure of the biological factor: PCR with mention of primers, polymerase type, general reaction conditions (concentration of the various reagents, cycle number, duration and temperature of the various steps); DNA-sequencing with the 
method used, the electrophoresis characteristics (gel composition, duration, temperature and generator voltage) and revelation procedure; reverse transcription (RT) with the transcriptase-reverse type and general conditions of incubation (reagent concentration, temperature and duration); SSCP with the gel composition (acrylamide percentage, glycerol content), other electrophoresis characteristics (duration, temperature and generator voltage), coloration method (the SSCP must be followed by the abnormally migrated fragments sequencing if there is no negative internal control); DGGE with gel composition and gel composition gradient, other electrophoresis characteristics (duration, temperature and generator voltage) and coloration method (the DGGE must be followed by the abnormally migrated fragments sequencing if there is no negative internal control); restricted fragment length polymorphism (RFLP) with the restriction enzyme type, temperature and incubation time, electrophoresis characteristics (gel composition, duration, temperature and generator voltage), coloration method (the RFLP must be followed by the abnormally migrated fragments sequencing if there is no negative internal control); IHC with the first antibody type and clone identification, second antibody type, reaction characteristics (antibodies concentration, duration and temperature of incubation), colouration method (peroxydase, alkaline phosphatase or chromagenic method), epitope unmasking method in case of fixed tissue, endogenous peroxydase activity inhibition method if the colouration method requires peroxydase; ELISA with the type of antibodies/antigens used, general reaction conditions (reagents concentration, temperature, duration), unspecific sites blockage (type of serum used), colouration and reading methods (fluorometry, spectrophotometry, etc.); Western blot with types of antibodies/antigens used, gel composition, other electrophoresis characteristics (duration, temperature, generator voltage), colouration method; immunoblot with the type of antibodies/antigens used, the type of membrane, other electrophoresis characteristics (duration, temperature, generator voltage), colouration method.

5. Description of the negative and positive control procedures.

6. Test reproducibility control: between investigator's centres if the study is multicentric, or inside the centre if it is unicentric.

7. Definition of the level of positivity of the test (only evaluated in case of IHC): validated (2 points); arbitrary (1 point); not described (0 point).

\section{Generalizability}

1. Patient selection criteria, including histological type, disease stage and treatment.
2. Patients' characteristics, including histology type, disease stage and treatment.

3. Initial workup.

4. Treatment description.

5. Source of samples.

6. Number of unassessable samples with exclusion causes.

\section{Results analysis}

1. Follow-up description, including the number of events.

2. Survival analysis according to the biological marker.

3. Univariate analysis of the prognostic factors for survival: report of the relative risk with the confidence interval (2 points); results without evaluation of the relative risk and its confidence interval (1 point); not reported or inadequate (0 point)

4. Multivariate analysis of the prognostic factors for survival: report of the relative risk with the confidence interval ( 2 points); results without evaluation of the relative risk and its confidence interval (1 point); not reported or inadequate (0 point).

\footnotetext{
Acknowledgements. The authors would like to thank D. Larsimont, P. Martiat, P. Vermylen, B. Martin, D. Gancberg and L. Lespagnard for their assistance in the design of the methodological scale for biological prognostic factors.
}

\section{References}

1. Paesmans M, Sculier J-P. Facteurs pronostiques des cancers bronchopulmonaires. In: Milleron B, Depierre A eds.Cancers Bronchopulmonaires. France, Arnette, 1998; pp. 239-247.

2. Paesmans M, Sculier JP, Lecomte J, et al. for the European Lung Cancer Working Party. Prognostic factors in patients with small cell lung cancer: analysis of a series of 763 patients included in four consecutive prospective trials and with a minimal 5-year follow-up duration. Cancer 2000; 89: 523-533.

3. Strauss GM. Prognostic markers in resectable nonsmall cell lung cancer. Hematol Oncol Clin North Am 1997; 11: 409-434.

4. Paesmans M, Sculier JP, Libert P, et al. Prognostic factors for survival in advanced non-small-cell lung cancer: univariate and multivariate analyses including recursive partitioning and amalgamation algorithms in 1,052 patients. The European Lung Cancer Working Party. J Clin Oncol 1995; 13: 1221-1230.

5. Buccheri G, Ferrigno D. Prognostic factors in lung cancer: tables and comments. Eur Respir J 1994; 7: $1350-1364$.

6. Kanters SD, Lammers JW, Voest EE. Molecular and biological factors in the prognosis of non-small cell lung cancer. Eur Respir J 1995; 8: 1389-1397. 
7. O'Byrne KJ, Koukourakis MI, Giatromanolaki A, et al. Vascular endothelial growth factor, plateletderived endothelial cell growth factor and angiogenesis in non-small cell lung cancer. $\mathrm{Br} J$ Cancer 2000; 82: 1427-1432.

8. Brambilla E, Negoescu A, Gazzeri S, et al. Apoptosisrelated factors $\mathrm{p} 53, \mathrm{Bcl} 2$, and $\mathrm{Bax}$ in neuroendocrine lung tumors. Am J Pathol 1996; 149: 1941-1952.

9. D'Amico TA, Massey M, Herndon JE, Moore MB, Harpole DH Jr. A biologic risk model for stage I lung cancer: immunohistochemical analysis of 408 patients with the use of ten molecular markers. $J$ Thorac Cardiovasc Surg 1999; 117: 736-743.

10. Kim YC, Park KO, Kern JA, et al. The interactive effect of Ras, HER2, p53 and Bcl-2 expression in predicting the survival of non-small cell lung cancer patients. Lung Cancer 1998; 22: 181-190.

11. Kwiatkowski DJ, Harpole DH Jr, Godleski J, et al. Molecular pathologic substaging in 244 stage I nonsmall-cell lung cancer patients: clinical implications. J Clin Oncol 1998; 16: 2468-2477.

12. Ferreira CG, Tolis C, Giaccone G. P53 and chemosensitivity. Ann Oncol 1999; 10: 1011-1021.

13. Brambilla E, Brambilla C. P53 and lung cancer. Pathol Biol (Paris) 1997; 45: 852-863.

14. Greenblatt MS, Bennett WP, Hollstein M, Harris CC. Mutations in the p53 tumor suppressor gene: clues to cancer etiology and molecular pathogenesis. Cancer Res 1994; 54: 4855-4878.

15. Parmar MKB, Torri V, Stewart L. Extracting summary statistics to perform meta-analyses of the published literature for survival endpoints. Statist Med 1998; 17: 2815-2834.

16. Yusuf S, Peto R, Lewis J, Collins R, Sleight P. Beta blockade during and after myocardial infarction: an overview of the randomized trials. Prog Cardiovasc Dis 1985; 27: 335-371.

17. Apolinario RM, van der $\mathrm{V}$, de Jong JS, et al. Prognostic value of the expression of $\mathrm{p} 53, \mathrm{Bcl}-2$, and Bax oncoproteins, and neovascularization in patients with radically resected non-small-cell lung cancer. J Clin Oncol 1997; 15: 2456-2466.

18. Bergqvist $\mathrm{M}$, Brattstrom $\mathrm{D}$, Larsson $\mathrm{A}$, et al. P53 auto-antibodies in non-small cell lung cancer patients can predict increased life expectancy after radiotherapy. Anticancer Res 1998; 18: 1999-2002.

19. Brambilla E, Gazzeri S, Moro D, et al. Immunohistochemical study of p53 in human lung carcinomas. Am J Pathol 1993; 143: 199-210.

20. Carbone DP, Mitsudomi T, Chiba I, et al. P53 immunostaining positivity is associated with reduced survival and is imperfectly correlated with gene mutations in resected non-small cell lung cancer. A Preliminary Report of LCSG 871. Chest 1994; 106: 77S-381S

21. Chen Y, Sato M, Fujimura S, et al. Expression of $\mathrm{Bcl}-2$, Bax, and p53 proteins in carcinogenesis of squamous cell lung cancer. Anticancer Res 1999; 19: 1351-1356.

22. Dalquen P, Sauter G, Torhorst J, et al. Nuclear p53 overexpression is an independent prognostic parameter in node-negative non-small cell lung carcinoma. J Pathol 1996; 178: 53-58.

23. de Anta JM, Jassem E, Rosell R, et al. TP53 mutational pattern in Spanish and Polish non-small cell lung cancer patients: null mutations are associated with poor prognosis. Oncogene 1997; 15: 2951-2958.
24. Dobashi K, Sugio K, Osaki T, Oka T, Yasumoto K. Micrometastatic p53-positive cells in the lymph nodes of non-small-cell lung cancer: prognostic significance. J Thorac Cardiovasc Surg 1997; 114: 339-346.

25. Dosaka-Akita $\mathrm{H}, \mathrm{Hu} \mathrm{SX}$, Fujino $\mathrm{M}$, et al. Altered retinoblastoma protein expression in nonsmall cell lung cancer: its synergistic effects with altered Ras and p53 protein status on prognosis. Cancer 1997; 79: 1329-1337.

26. Ebina M, Steinberg SM, Mulshine JL, Linnoila RI. Relationship of p53 overexpression and up-regulation of proliferating cell nuclear antigen with the clinical course of non-small cell lung cancer. Cancer Res 1994; 54: 2496-2503.

27. Esposito V, Baldi A, De Luca A, et al. Prognostic value of p53 in non-small cell lung cancer: relationship with proliferating cell nuclear antigen and cigarette smoking. Hum Pathol 1997; 28: 233-237.

28. Fontanini $\mathrm{G}$, Vignati $\mathrm{S}$, Bigini $\mathrm{D}$, et al. Bcl-2 protein: a prognostic factor inversely correlated to p53 in nonsmall-cell lung cancer. Br J Cancer 1995; 71: 10031007.

29. Fontanini G, Vignati S, Bigini D, et al. Recurrence and death in non-small cell lung carcinomas: a prognostic model using pathological parameters, microvessel count, and gene protein products. Clin Cancer Res 1996; 2: 1067-1075.

30. Fontanini $\mathrm{G}$, Boldrini L, Vignati $\mathrm{S}$, et al. $\mathrm{Bcl} 2$ and $\mathrm{p} 53$ regulate vascular endothelial growth factor (VEGF)mediated angiogenesis in non-small cell lung carcinoma. Eur J Cancer 1998; 34: 718-723.

31. Fu XL, Zhu XZ, Shi DR, et al. Study of prognostic predictors for non-small cell lung Cancer. Lung Cancer 1999; 23: 143-152.

32. Fujino M, Dosaka-Akita H, Harada M, et al. Prognostic significance of $\mathrm{p} 53$ and Ras $\mathrm{P} 21$ expression in nonsmall cell lung cancer. Cancer 1995; 76: 2457-2463.

33. Fukuyama $\mathrm{Y}$, Mitsudomi $\mathrm{T}$, Sugio $\mathrm{K}$, Ishida $\mathrm{T}$, Akazawa K, Sugimachi K. K-Ras and p53 mutations are an independent unfavourable prognostic indicator in patients with non-small-cell lung cancer. Br J Cancer 1997; 75: 1125-1130.

34. Geradts J, Fong KM, Zimmerman PV, Maynard R, Minna JD. Correlation of abnormal RB, P16ink4a, and $\mathrm{p} 53$ expression with $3 \mathrm{p}$ loss of heterozygosity, other genetic abnormalities, and clinical features in 103 primary non-small cell lung cancers. Clin Cancer Res 1999; 5: 791-800.

35. Giatromanolaki A, Koukourakis $\mathrm{M}, \mathrm{O}^{\prime}$ Byrne $\mathrm{K}$, et al. Prognostic value of angiogenesis in operable nonsmall cell lung cancer. J Pathol 1996; 179: 80-88.

36. Greatens TM, Niehans GA, Rubins JB, et al. Do molecular markers predict survival in non-small-cell lung cancer? Am J Respir Crit Care Med 1998; 157: 1093-1097.

37. Guang SG, Ogura T, Sekine I, et al. Association between p53 mutation and clinicopathological features of non-small cell lung cancer. Jpn J Clin Oncol 1997; 27: 211-215.

38. Harpole DH Jr, Marks JR, Richards WG, Herndon JE, Sugarbaker DJ. Localized adenocarcinoma of the lung: oncogene expression of ErbB-2 and p53 in 150 patients. Clin Cancer Res 1995; 1: 659-664.

39. Harpole DH Jr, Herndon JE, Wolfe WG, et al. A prognostic model of recurrence and death in stage I non-small cell lung cancer utilizing presentation, 
histopathology, and oncoprotein expression. Cancer Res 1995; 55: 51-56.

40. Harpole DH Jr, Richards WG, Herndon JE, Sugarbaker DJ. Angiogenesis and molecular biologic substaging in patients with stage I non-small cell lung cancer. Ann Thorac Surg 1996; 61: 1470-1476.

41. Hayakawa K, Mitsuhashi N, Hasegawa M, et al. The prognostic significance of immunohistochemically detected p53 protein expression in non-small cell lung cancer treated with radiation therapy. Anticancer Res 1998; 18: 3685-3688.

42. Horio Y, Takahashi T, Kuroishi T, et al. Prognostic significance of p53 mutations and $3 p$ deletions in primary resected non-small cell lung cancer. Cancer Res 1993; 53: 1-4.

43. Huang CL, Taki T, Adachi M, et al. Mutations of p53 and K-Ras genes as prognostic factors for non-small cell lung cancer. Int J Oncol 1998; 12: 553-563.

44. Huang C, Taki T, Adachi M, Konishi T, Higashiyama M, Miyake M. Mutations in exon 7 and 8 of p53 as poor prognostic factors in patients with non-small cell lung cancer. Oncogene 1998; 16: 2469-2477.

45. Ishida $\mathrm{H}$, Irie $\mathrm{K}$, Itoh $\mathrm{T}$, Furukawa $\mathrm{T}$, Tokunaga $\mathrm{O}$. The prognostic significance of $\mathrm{p} 53$ and $\mathrm{Bcl}-2$ expression in lung adenocarcinoma and its correlation with Ki-67 growth fraction. Cancer 1997; 80: 1034-1045.

46. Kandioler-Eckersberger D, Kappel S, Mittlbock M, et al. The TP53 genotype but not immunohistochemical result is predictive of response to cisplatin-based neoadjuvant therapy in stage III non-small cell lung cancer. J Thorac Cardiovasc Surg 1999; 117: 744-750.

47. Kawasaki M, Noguchi M, Morikawa A, et al. Nuclear p53 accumulation by small-sized adenocarcinomas of the lung. Pathol Int 1996; 46: 486-490.

48. Kawasaki M, Nakanishi Y, Kuwano K, Yatsunami J, Takayama K, Hara N. The utility of p53 immunostaining of transbronchial biopsy specimens of lung cancer: p53 overexpression predicts poor prognosis and chemoresistance in advanced non-small cell lung cancer. Clin Cancer Res 1997; 3: 1195-1200.

49. Komaki R, Milas L, Ro JY, et al. Prognostic biomarker study in pathologically staged N1 nonsmall cell lung cancer. Int J Radiat Oncol Biol Phys 1998; 40: 787-796.

50. Komiya T, Hirashima T, Takada M, et al. Prognostic significance of serum p53 antibodies in squamous cell carcinoma of the lung. Anticancer Res 1997; 17: 37213724.

51. Kondo K, Tsuzuki H, Sasa M, Sumitomo M, Uyama T, Monden YA. Dose-response relationship between the frequency of p53 mutations and tobacco consumption in lung cancer patients. J Surg Oncol 1996; 61: $20-26$

52. Konishi T, Lin Z, Fujino S, Kato H, Mori A. Association of $\mathrm{p} 53$ protein expression in stage I lung adenocarcinoma with reference to cytological subtypes. Hum Pathol 1997; 28: 544-548.

53. Kwa HB, Michalides RJ, Dijkman JH, Mooi WJ. The prognostic value of NCAM, p53 and cyclin D1 in resected non-small cell lung cancer. Lung Cancer 1996; 14: 207-217.

54. Lai CL, Tsai CM, Tsai TT, et al. Presence of serum anti-p53 antibodies is associated with pleural effusion and poor prognosis in lung cancer patients. Clin Cancer Res 1998; 4: 3025-3030.

55. Langendijk JA, Thunnissen FB, Lamers RJ, et al. The prognostic significance of accumulation of $\mathrm{p} 53$ protein in stage III non-small cell lung cancer treated by radiotherapy. Radiother Oncol 1995; 36: 218-224.

56. Laudanski J, Burzykowski T, Niklinska W, Chyczewski K, Furman M, Niklinski J. Prognostic value of serum p53 antibodies in patients with resected non-small cell lung cancer. Lung Cancer 1998; 22: 191-200.

57. Lavezzi AM, Santambrogio L, Bellaviti N, et al. Prognostic significance of different biomarkers in non-small cell lung cancer. Oncol Rep 1999; 6: 819825.

58. Lee JS, Yoon A, Kalapurakal SK, et al. Expression of p53 oncoprotein in non-small-cell lung cancer: a favorable prognostic factor. J Clin Oncol 1995; 13: 1893-1903.

59. Levesque MA, D'Costa M, Spratt EH, Yaman MM, Diamandis EP. Quantitative analysis of p53 protein in non-small cell lung cancer and its prognostic value. Int $J$ Cancer 1998; 79: 494-501.

60. Lohmann D, Putz B, Reich U, Bohm J, Prauer H, Hofler H. Mutational spectrum of the p53 gene in human small-cell lung cancer and relationship to clinicopathological data. Am J Pathol 1993; 142: 907-915.

61. Lucchi M, Fontanini G, Mussi A, et al. Tumor angiogenesis and biologic markers in resected stage I NSCLC. Eur J Cardiothorac Surg 1997; 12: 535-541.

62. Macchiarini P, Fontanini G, Dulmet E, et al. Angiogenesis: an indicator of metastasis in non-small cell lung cancer invading the thoracic inlet. Ann Thorac Surg 1994; 57: 1534-1539.

63. MacKinnon M, Kerr KM, King G, Kennedy MM, Cockburn JS, Jeffrey RR. P53, C-ErbB-2 and Nm23 expression have no prognostic significance in primary pulmonary adenocarcinoma. Eur J Cardiothorac Surg 1997; 11: 838-842.

64. McLaren R, Kuzu I, Dunnill M, Harris A, Lane D, Gatter KC. The relationship of p53 immunostaining to survival in carcinoma of the lung. Br J Cancer 1992; 66: 735-738.

65. Mitsudomi T, Oyama T, Kusano T, Osaki T, Nakanishi R, Shirakusa T. Mutations of the p53 gene as a predictor of poor prognosis in patients with non-small-cell lung cancer. J Natl Cancer Inst 1993; 85: 2018-2023.

66. Mitsudomi T, Suzuki S, Yatabe Y, et al. Clinical implications of p53 autoantibodies in the sera of patients with non-small-cell lung cancer. $J$ Natl Cancer Inst 1998; 90: 1563-1568.

67. Miyake M, Adachi M, Huang C, Higashiyama M, Kodama K, Taki $\mathrm{T}$. A novel molecular staging protocol for non-small cell lung cancer. Oncogene 1999; 18: 2397-2404.

68. Moldvay J, Strausz J, Egervary M, et al. P53 expression in stage i squamous cell lung cancer. Pathol Oncol Res 1998; 4: 8-13.

69. Morkve O, Halvorsen OJ, Skjaerven R, Stangeland L, Gulsvik A, Laerum OD. Prognostic significance of p53 protein expression and DNA ploidy in surgically treated non-small cell lung carcinomas. Anticancer Res 1993; 13: 571-578.

70. Murakami I, Fujiwara Y, Yamaoka N, Hiyama K, Ishioka S, Yamakido M. Detection of p53 gene mutations in cytopathology and biopsy specimens from patients with lung cancer. Am J Respir Crit Care Med 1996; 154: 1117-1123.

71. Nishio M, Koshikawa T, Kuroishi T, et al. Prognostic 
significance of abnormal p53 accumulation in primary, resected non-small-cell lung cancers. $J$ Clin Oncol 1996; 14: 497-502.

72. Nishio M, Koshikawa $\mathrm{T}$, Yatabe $\mathrm{Y}$. Prognostic significance of cyclin D1 and retinoblastoma expression in combination with p53 abnormalities in primary, resected non-small cell lung cancers. Clin Cancer Res 1997; 3: 1051-1058.

73. O'Neill AJ, Staunton MJ, Gaffney EF. Apoptosis occurs independently of Bcl-2 and p53 over-expression in non-small cell lung carcinoma. Histopathology 1996; 29: 45-50.

74. Ohsaki Y, Toyoshima E, Fujiuchi S, et al. Bcl-2 and p53 protein expression in non-small cell lung cancers: correlation with survival time. Clin Cancer Res 1996; 2: 915-920.

75. Pappot H, Francis D, Brunner N, Grondahl-Hansen $\mathrm{J}$, Osterlind K. P53 protein in non-small cell lung cancer as quantitated by enzyme-linked immunosorbent assay: relation to prognosis. Clin Cancer Res 1996; 2: 155-160.

76. Pastorino U, Andreola S, Tagliabue E, et al. Immunocytochemical markers in stage I lung cancer: relevance to prognosis. J Clin Oncol 1997; 15: 2858-2865.

77. Przygodzki RM, Finkelstein SD, Langer JC, et al. Analysis of $\mathrm{p} 53$, K-Ras-2, and C-Raf-1 in pulmonary neuroendocrine tumors. Correlation with histological subtype and clinical outcome. Am J Pathol 1996; 148: 1531-1541.

78. Quantin X, Pujol JL, Lehmann M, Simony J, Serre I, Michel FB. Immunohistochemical detection of p53 protein and prognosis of surgically resected nonsmall-cell lung cancer. Cancer Detect Prev 1997; 21: 418-425.

79. Quinlan DC, Davidson AG, Summers CL, Warden HE, Doshi HM. Accumulation of p53 protein correlates with a poor prognosis in human lung cancer. Cancer Res 1992; 52: 4828-4831.

80. Roncalli M, Doglioni C, Springall DR, et al. Abnormal p53 expression in lung neuroendocrine tumors. Diagnostic and prognostic implications. Diagn $\mathrm{Mol}$ Pathol 1992; 1: 129-135.

81. Rosell R, Pifarre A, Monzo M, et al. Reduced survival in patients with stage-I non-small-cell lung cancer associated with DNA-replication errors. Int J Cancer 1997; 74: 330-334.

82. Rosenfeld MR, Malats N, Schramm L, et al. Serum anti-p53 antibodies and prognosis of patients with small-cell lung cancer. J Natl Cancer Inst 1997; 89: 381-385.

83. Tagawa M, Murata M, Kimura H. Prognostic value of mutations and a germ line polymorphism of the p53 gene in non-small cell lung carcinoma: association with clinicopathological features. Cancer Lett 1998; 128: 93-99.

84. Tanaka F, Miyahara R, Ohtake Y, et al. Antigen expression and postoperative survival in non-small cell lung cancer. Ann Thorac Surg 1998; 66: 17451750 .

85. Tanaka F, Yanagihara K, Ohtake Y, et al. P53 status predicts the efficacy of postoperative oral administration of tegafur for completely resected non-small cell lung cancer. Jpn J Cancer Res 1999; 90: 432-438.

86. Tomizawa Y, Kohno T, Fujita T, et al. Correlation between the status of the p53 gene and survival in patients with stage I non-small cell lung carcinoma. Oncogene 1999; 18: 1007-1014.
87. Tomizawa Y, Adachi J, Kohno T, et al. Prognostic significance of allelic imbalances on chromosome $9 p$ in stage I non-small cell lung carcinoma. Clin Cancer Res 1999; 5: 1139-1146.

88. Top B, Mooi WJ, Klaver SG, et al. Comparative analysis of $\mathrm{p} 53$ gene mutations and protein accumulation in human non-small-cell lung cancer. Int J Cancer 1995; 64: 83-91.

89. Tormanen U, Eerola AK, Rainio P, et al. Enhanced apoptosis predicts shortened survival in non-small cell lung carcinoma. Cancer Res 1995; 55: 55955602.

90. Vega FJ, Iniesta $\mathrm{P}$, Caldes $\mathrm{T}$, et al. P53 exon 5 mutations as a prognostic indicator of shortened survival in non-small-cell lung cancer. $\mathrm{Br} J$ Cancer 1997; 76: 44-51.

91. Volm M, Efferth T, Mattern J. Oncoprotein (c-Myc, C-ErbB1, C-ErbB2, C-Fos) and Suppressor Gene Product (P53) Expression in Squamous Cell Carcinomas of the Lung. Clinical and Biological Correlations. Anticancer Res 1992; 12: 11-20.

92. Xu HJ, Cagle PT, Hu SX, Li J, Benedict WF. Altered retinoblastoma and $12 \mathrm{p} 53$ protein status in nonsmall cell carcinoma of the lung: potential synergistic effects on prognosis. Clin Cancer Res 1996; 2: 1169 1176.

93. Roth JA, Swisher SG, Meyn RE. P53 tumor suppressor gene therapy for cancer. Oncology 1999; 13: $148-154$.

94. Swisher SG, Roth JA, Nemunaitis J, et al. Adenovirus-mediated p53 gene transfer in advanced nonsmall-cell lung cancer. J Natl Cancer Inst 1999; 91: 763-771.

95. Sculier JP, Berghmans T, Castaigne C, et al. Maintenance chemotherapy for small cell lung cancer: a critical review of the literature. Lung Cancer 1998; 19: 141-151.

96. Luce S, Paesmans M, Berghmans T, et al. Revue critique des études randomisées évaluant le rôle de la radiothérapie dans le traitement du cancer bronchique à petites cellules au stade limité. Rev Mal Respir 1998; 15: 633-641.

97. Meert AP, Berghmans T, Branle F, et al. Phase II and III with new drugs for non-small cell lung cancer: a systematic review of the literature with a methodology quality assessment. Anticancer Res 1999; 19: 43794390.

98. Mascaux C, Paesmans M, Berghmans T, et al. A systematic review of the role of etoposide and cisplatin in the chemotherapy of small cell lung cancer with methodology assessment and meta-analysis. Lung Cancer 2000; 30: 23-26.

99. Egger M, Zellweger-Zahner T, Schneider M, Junker $\mathrm{C}$, Lengeler C, Antes G. Language bias in randomised controlled trials published in English and German. Lancet 1997; 350: 326-329.

100. Hollstein M, Sidransky D, Vogelstein B, Harris CC. P53 mutations in human cancers. Science 1991; 253: 49-53.

101. Levine AJ, Perry ME, Chang A, et al. The 1993 Walter Hubert lecture: the role of the p53 tumoursuppressor gene in tumorigenesis. Br J Cancer 1994; 69: 409-416.

102. Cho Y, Gorina S, Jeffrey PD, Pavletich NP. Crystal structure of a p53 tumor suppressor-DNA complex: understanding tumorigenic mutations. Science 1994; 265: 346-355. 
103. Tominaga O, Hamelin R, Remvikos Y, Salmon RJ, Thomas G. P53 from basic research to clinical applications. Crit Rev Oncog 1992; 3: 257-282.

104. Vojtesek B, Bartek J, Midgley CA, Lane DP. An immunochemical analysis of the human nuclear phosphoprotein p53. New monoclonal antibodies and epitope mapping using recombinant p53. J Immunol Methods 1992; 151: 237-244.

105. Cattoretti G, Pileri S, Parravicini C, et al. Antigen unmasking on formalin-fixed, paraffin-embedded tissue sections. J Pathol 1993; 171: 83-98.

106. Bodner SM, Minna JD, Jensen SM, et al. Expression of mutant $\mathrm{p} 53$ proteins in lung cancer correlates with the class of p53 gene mutation. Oncogene 1992; 7: 743-749.

107. Kastan MB, Radin AI, Kuerbitz SJ, et al. Levels of p53 protein increase with maturation in human hematopoietic cells. Cancer Res 1991; 51: 42794286.

108. Kastan MB, Onyekwere O, Sidransky D, Vogelstein $\mathrm{B}$, Craig RW. Participation of $\mathrm{p} 53$ protein in the cellular response to DNA damage. Cancer Res 1991; 51: 6304-6311.

109. Hall PA, McKee PH, Menage HD, Dover R, Lane DP. High levels of p53 protein in UV-irradiated normal human skin. Oncogene 1993; 8: 203-207.

110. Stewart A, Parmar K. Meta-analysis of the literature or of individual patient data: is there a difference? Lancet 1993; 341: 418-422.

111. Cappelleri J, Loannidis J, Schmid C, et al. Large trials versus meta-analysis of smaller trials. JAMA 1996; 276: $1332-1338$. 